\title{
The Air Quality during the Confinement and Coronavirus 2020-2021 Period: The Case of Tunisia ${ }^{\dagger}$
}

\author{
Abderrazak Arif (1D) \\ Institut National de la Météorologie, B.P. 156, Tunis-Carthage 2035, Tunisia; abderrazak.001@gmail.com or \\ abderrazak.arif@meteo.tn \\ + Presented at the 4th International Electronic Conference on Atmospheric Sciences, 16-31 July 2021; \\ Available online https: / / ecas2021.sciforum.net/.
}

check for updates

Citation: Arif, A. The Air Quality during the Confinement and Coronavirus 2020-2021 Period: The Case of Tunisia. Environ. Sci. Proc. 2021, 8, 9. https://doi.org/10.3390/ ecas2021-10328

Academic Editor: Anthony R. Lupo

Published: 22 June 2021

Publisher's Note: MDPI stays neutral with regard to jurisdictional claims in published maps and institutional affiliations.

Copyright: (C) 2021 by the author. Licensee MDPI, Basel, Switzerland. This article is an open access article distributed under the terms and conditions of the Creative Commons Attribution (CC BY) license (https:// creativecommons.org/licenses/by/ $4.0 /)$.

\begin{abstract}
At the end of 2019, the first case of coronavirus (COVID-19) was reported in Wuhan, China. A month later, that epidemic turned into a national crisis, with infected individuals diagnosed all over China. In early March 2020, the World Health Organization (WHO) declared that the Wuhan epidemic had turned into a global pandemic. Many European countries had started to experience several cases affected by this coronavirus, which was known to be highly contagious. The WHO launched several recommendations to curb the spread of this virus and called for general confinement establishment in the affected countries. Tunisia quickly took this step on 22 March 2020 and announced immediate general confinement for two weeks, renewable according to the test results. Factories were closed to limit human damage. International flights were halted and the majority of government and private services were halted except minimum and emergency services. Following these successive events, the air quality improved markedly during the confinement period. NASA scientists say the reduction in nitrogen dioxide $\left(\mathrm{NO}_{2}\right)$ pollution first appeared near Wuhan, Northern Italy, and France, and they experienced a reduction of nearly $50 \%$ of their $\mathrm{NO}_{2}$ emissions during this first confinement period (March-April 2020); $\mathrm{NO}_{2}$ emissions were reduced by almost $30 \%$ in China. In Tunisia, $\mathrm{NO}_{2}$, sulfur dioxide $\left(\mathrm{SO}_{2}\right)$ and carbon monoxide $(\mathrm{CO})$ showed a remarkable decrease in the north and the center of Tunisia of more than $40 \%$ during this period, mainly linked to the reduction in emissions from road traffic and industries. Additionally, these pollutant gas concentrations were reduced by nearly $50 \%$ during the third pandemic wave, during the period of January-April 2021. Consequently, the air quality has improved significantly in Tunisia and around the world.
\end{abstract}

Keywords: COVID-19; pandemic; activities; coronavirus; meteorological; Tunisia; pollution; air; health; pollutant

\section{Introduction}

Air quality improved significantly during the first confinement that lasted almost a month and a half (March and April 2020) in Tunisia. This period is characterized by the first wave of the new epidemic that began in Wuhan, China at the end of 2019, where the first case of coronavirus (COVID-19) was reported [1]. Later, this epidemic turned into a national crisis, with infected individuals diagnosed across the country $[2,3]$. Transportation and travel to and from Wuhan were halted. Then, they closed schools and universities to reduce the spread of the disease and established numerous quarantines [4]. In early March 2020, the World Health Organization (WHO) declared that the epidemic in Wuhan had turned into a global pandemic as several countries in North America and Europe had been affected by this COVID-19 coronavirus [5]. Italy, France, Spain and other European countries had experienced several cases affected by this coronavirus, known to be very contagious. The WHO launched several recommendations to curb the spread of this virus and called for the establishment of general confinement in the affected countries. Tunisia quickly took this step on 22 March 2020, and announced immediate general confinement 
for two weeks, renewable according to the results of the tests. Travel between towns was banned. Factories were closed to limit human damage.

To curb the virus spread and called for the establishment of general confinement in the affected countries, international flights were halted, and the majority of government and private services were halted except minimum and emergency services. A dramatic decrease in nitrogen dioxide $\left(\mathrm{NO}_{2}\right)$, sulfur dioxide $\left(\mathrm{SO}_{2}\right)$ and carbon monoxide $(\mathrm{CO})$, which are polluting gases caused mainly by human activities, was observed during the confinement period in several Tunisian cities, in particular in the north and in the center, using satellite measurements of the European Center with the European Earth Monitoring Program-COPERNICUS. The data were analyzed and developed at the National Institute of Meteorology, Tunisia. Following these successive events, the air quality improved markedly during this confinement period of March and April 2020; known as the COVID19 first wave [6]. A spectacular fall in nitrogen dioxide $\left(\mathrm{NO}_{2}\right)$, sulfur dioxide $\left(\mathrm{SO}_{2}\right)$ and carbon monoxide (CO) produced mainly by human activities was observed during this period in several Tunisian regions, using satellite measurements of Sentinel-5P. As $\mathrm{NO}_{2}$ is a common tracer of air pollution linked to human activity, and associated with morbidity and mortality [7-10], NASA scientists said that the reduction in this pollutant $\left(\mathrm{NO}_{2}\right)$ appeared first near Wuhan, but spread to the rest of the country, and eventually worldwide $[5,10]$. Additionally, Northern Italy and France saw a reduction of nearly $50 \%$ of their $\mathrm{NO}_{2}$ emissions during this confinement period. In central China, $\mathrm{NO}_{2}$ emissions were reduced by almost $25 \%$ [5]. $\mathrm{SO}_{2}$ emissions, another common marker of air pollution, fell by over $60 \%$ in northern Tunisia [6], in Mumbai, New York and Los Angeles by nearly 33\%, in Madrid by $50 \%$, in Seoul by $50 \%$, and in Wuhan by $42 \%$ [11]. Air pollution is responsible for many deaths and an increased incidence of respiratory illnesses [12]. According to the World Health Organization (WHO), nearly 4.6 million people die each year from diseases related to poor air quality $[13,14]$, and it is therefore responsible for more deaths each year than motor vehicle accidents [15]. Deaths associated with air pollution include, but are not limited to, aggravated asthma, bronchitis, emphysema, lung and heart disease, and respiratory allergies [12]. China, where the COVID-19 epidemic began, is also a country severely affected by air pollution [8,9]. Air pollution in China is responsible for 4000 deaths every day, or 1.6 million deaths in 2016 [16,17]. Scientific studies have mentioned that mortality due to air pollution represents a rate of $0.13 \%$ per day [8,9], to $2 \%$ for $10 \mu \mathrm{g} / \mathrm{m}^{3}$ of $\mathrm{NO}_{2}$ over a period of five days $[18,19]$. Considering the huge decrease in air pollution following quarantine around the world, the COVID-19 pandemic paradoxically could have reduced the total number of deaths during this period by drastically reducing the number of deaths due to air pollution. Moreover, in addition to the reduced deaths from air pollution, the reduction could also have positive benefits in reducing preventable non-transmissible diseases.

\section{Methods}

To study the air pollution in Tunisia during the COVID-19 period, we collected satellite measurements (Sentinel-5P satellite) from before and after this pandemic. Tunisia is the northernmost country in Africa, covering nearly $164,000 \mathrm{~km}^{2}$, and with a population of nearly 12 million; 4 million inhabitants live in Grand-Tunis, located in the north of the country (Ariana, Ben Arous, Manouba and Tunis). These four governorates are found on the Capital outskirts, Tunis. This large agglomeration represents an important concentration of the Tunisian population, the region most affected by COVID-19 since the start of this pandemic, and characterized by considerable industrial activity.

As the majority of Tunisian cities have been infected by this new coronavirus since the appearance of this COVID-19 pandemic, we have selected the air pollution data from the year 2019 (one year before this pandemic) until to date (May 2021), in order to analyze the trends of pollutants before and after this phenomenon. We used data collected daily from 00h TU to calculate the monthly mean concentrations of the four air pollutants; namely carbon monoxide $(\mathrm{CO})$, sulfur dioxide $\left(\mathrm{SO}_{2}\right)$, nitrogen dioxide $\left(\mathrm{NO}_{2}\right)$ and ozone 
$\left(\mathrm{O}_{3}\right)$ (Table 1). We monitored the monthly trends of these pollutants from the onset of this pandemic (beginning December 2019 and January 2020) in order to compare them with previous periods. Since the appearance of the first COVID-19 wave which began in March-April 2020, the air quality has been changed mainly, on the one hand, due to country actions attempting to contain the COVID-19 spread, and on the other hand, by the general atmospheric circulation. We looked at the air pollution during the first four months of 2020 and assessed whether there were linear trends in pollutant concentrations due to the protection and confinement measures imposed by the government due to this pandemic. We then compared these concentrations before and after COVID-19 for the majority of the affected cities.

Table 1. Monthly mean of the surface pollutants $\left(\mathrm{SO}_{2}, \mathrm{NO}_{2}, \mathrm{O}_{3}\right.$ and $\mathrm{CO}$, unit: $\left.\mu \mathrm{g} / \mathrm{m}^{3}\right)$ for Tunisia domain, 2019,2020 and 2021 period, 00h UTC using Sentinel-5P satellite.

\begin{tabular}{lcccccccccccc}
\hline & $\mathbf{S O}_{2}$ & \multicolumn{3}{c}{$\mathrm{NO}_{\mathbf{2}}$} & & & $\mathrm{O}_{3}$ & \multicolumn{3}{c}{$\mathrm{CO}$} \\
\cline { 2 - 12 } & $\mathbf{2 0 1 9}$ & $\mathbf{2 0 2 0}$ & $\mathbf{2 0 2 1}$ & $\mathbf{2 0 1 9}$ & $\mathbf{2 0 2 0}$ & $\mathbf{2 0 2 1}$ & $\mathbf{2 0 1 9}$ & $\mathbf{2 0 2 0}$ & $\mathbf{2 0 2 1}$ & $\mathbf{2 0 1 9}$ & $\mathbf{2 0 2 0}$ & $\mathbf{2 0 2 1}$ \\
\hline January & 7.62 & 3.79 & 0.76 & 7.35 & 5.61 & 2.66 & 45.45 & 46.01 & 47.8 & 195.08 & 173.32 & 136.09 \\
\hline February & 9.38 & 3.54 & 1.57 & 9.28 & 6.61 & 3.95 & 45.84 & 50.47 & 52.57 & 222.91 & 162.72 & 167.85 \\
\hline March & 10.14 & 2.62 & 1.42 & 10.43 & 4.05 & 2.93 & 48.67 & 59.8 & 58.49 & 235.81 & 152.92 & 151.24 \\
\hline April & 10.21 & 3.85 & 1.35 & 9.03 & 4.69 & 2.49 & 58.93 & 59.26 & 62.77 & 212.67 & 164.86 & 145.94 \\
\hline May & 9.7 & 2.49 & 1.31 & 8.78 & 3.96 & 2.65 & 66.47 & 62.38 & 58.7 & 181.44 & 136.81 & 121.48 \\
\hline June & 13.84 & 2.66 & 2.14 & 11.28 & 4.02 & 2.93 & 57.54 & 63 & 58.38 & 192 & 131.24 & 127.64 \\
\hline July & 13.73 & 2.56 & & 11.07 & 4.09 & & 57.03 & 57.45 & & 192.8 & 122.63 \\
\hline August & 3.22 & 3.04 & & 3.95 & 4.4 & & 59.47 & 59.2 & & 142.95 & 142.9 \\
\hline September & 3.33 & 2.96 & & 4.68 & 4.4 & & 53.65 & 57.14 & & 135.4 & 131.05 \\
\hline October & 2.91 & 1.44 & & 4.23 & 2.87 & & 53.92 & 54.22 & & 127.73 & 125.85 \\
\hline November & 2.02 & 1.19 & & 3.99 & 3.37 & & 47.18 & 48.57 & & 120.68 & 131.28 \\
\hline December & 2.58 & 0.91 & & 4.51 & 2.99 & & 44.86 & 45.59 & & 135.44 & 133.94 \\
\hline
\end{tabular}

\section{Results and Discussion}

To study the air quality during the COVID-19 pandemic apparition in Tunisia, we used the four pollutants' daily data; carbon monoxide $(\mathrm{CO})$, sulfur dioxide $\left(\mathrm{SO}_{2}\right)$, nitrogen dioxide $\left(\mathrm{NO}_{2}\right)$ and ozone $\left(\mathrm{O}_{3}\right)$, collected from COPERNICUS program satellite measurements. The mean monthly data treatment of these pollutants showed remarkable changes mainly during the first period of confinement 2020 and after, linked to the decrease in road traffic emissions and industries, influenced by the general atmospheric circulation on a regional and global scale. The ozone pollutant at surface level showed a slight growth due mainly to a combination of oxygen and nitrogen gases, which occurs most often in the context of high temperature combustion phenomena in the excess of oxygen presence. This type of combustion can occur in the context of natural phenomena, such as thunderstorms, a high temperature prevailing in the vicinity of lightning or around forest fires, and occurs as a result of human activities [20]. Monthly graphics have also been produced for the majority of Tunisian regions, making it possible to visualize the effects of confinement on air quality. It is interesting that in the nitrogen dioxide $\left(\mathrm{NO}_{2}\right)$, sulfur dioxide $\left(\mathrm{SO}_{2}\right)$, carbon monoxide (CO) and ozone $\left(\mathrm{O}_{3}\right)$ concentrations, the pollutants are known to have deleterious effects on human health. Here, we compare a normal situation (from the previous year, 2019) to the observed situation since the first COVID-19 wave of 2020 and the third COVID-19 wave beginning in January, 2021. This generalized decrease in pollution was observed to have an impact on health and climate. According to the data collected, all of Europe, North America and China have experienced this decrease. The monthly graphics show remarkable differences in these pollutant concentrations in Tunisia for April 2020 and 2021, 
compared to the previous April (Figures 5-8 and Table 2). The nitrogen dioxide $\left(\mathrm{NO}_{2}\right)$, sulfur dioxide $\left(\mathrm{SO}_{2}\right)$ and carbon monoxide $(\mathrm{CO})$ levels showed an important decrease in the north and the center of Tunisia, with more than $40 \%$ decrease during 2020 and 2021 confinement periods linked mainly to the emissions decreasing from road traffic and industries [6]. Conversely, Ozone $\left(\mathrm{O}_{3}\right)$ showed growth of nearly $20 \%$ in the center-west of Tunisia, and a slight decrease of $10 \%$ in the north-west and south [6]. The average growth of ozone was between $1 \%$ and $23 \%$ during the COVID-19 coronavirus first wave, and declined in summer 2020, the period of returning to normal life, and has continued in this pattern to the present day.

Table 2. Regional mean of the surface pollutants $\left(\mathrm{SO}_{2}, \mathrm{NO}_{2}, \mathrm{O}_{3}\right.$ and $\mathrm{CO}$, unit: $\left.\mu \mathrm{g} / \mathrm{m}^{3}\right)$ for Tunisia domain, April 2019, 2020 and 2021, 00h UTC using Sentinel-5P satellite.

\begin{tabular}{|c|c|c|c|c|c|c|c|c|c|c|c|c|}
\hline & $\mathrm{SO}_{2}$ & & & $\mathrm{NO}_{2}$ & & & $\mathrm{O}_{3}$ & & & $\mathrm{CO}$ & & \\
\hline & 2019 & 2020 & 2021 & 2019 & 2020 & 2021 & 2019 & 2020 & 2021 & 2019 & 2020 & 2021 \\
\hline Tunis & 44.87 & 22.49 & 3.66 & 36.99 & 16.57 & 11.10 & 38.48 & 48.53 & 47.59 & 469.04 & 361.00 & 265.43 \\
\hline Bizerte & 17.99 & 7.35 & 1.99 & 19.58 & 7.39 & 4.16 & 55.38 & 65.30 & 65.54 & 264.03 & 191.28 & 165.62 \\
\hline Nabeul & 10.11 & 2.81 & 1.69 & 10.90 & 3.90 & 3.23 & 61.05 & 76.35 & 73.58 & 212.36 & 143.54 & 149.84 \\
\hline Kelibia & 4.98 & 1.60 & 0.96 & 6.19 & 1.17 & 1.07 & 73.48 & 80.92 & 80.74 & 161.83 & 133.34 & 136.13 \\
\hline Ain Drahem & 12.06 & 1.45 & 1.03 & 11.52 & 3.68 & 3.03 & 52.60 & 55.18 & 49.02 & 250.39 & 153.73 & 143.26 \\
\hline Jendouba & 15.04 & 1.34 & 0.76 & 14.23 & 3.92 & 3.41 & 39.15 & 52.91 & 42.00 & 268.28 & 151.54 & 143.40 \\
\hline Le Kef & 10.84 & 1.81 & 0.72 & 9.58 & 3.14 & 2.63 & 44.69 & 62.22 & 53.78 & 214.40 & 142.76 & 135.91 \\
\hline Siliana & 10.13 & 1.40 & 0.75 & 9.43 & 2.49 & 1.92 & 50.13 & 70.64 & 66.26 & 219.45 & 141.40 & 136.16 \\
\hline Kairouane & 16.93 & 2.33 & 0.99 & 13.21 & 4.45 & 2.70 & 42.91 & 57.80 & 52.79 & 278.84 & 162.69 & 148.39 \\
\hline Kasserine & 8.31 & 1.84 & 0.58 & 6.21 & 2.99 & 1.71 & 47.30 & 70.25 & 66.95 & 186.41 & 145.34 & 134.41 \\
\hline Mahdia & 3.58 & 1.62 & 0.74 & 3.12 & 0.89 & 1.10 & 77.53 & 79.12 & 77.59 & 157.13 & 134.51 & 136.22 \\
\hline Sousse & 8.44 & 3.38 & 1.57 & 9.06 & 11.27 & 3.51 & 64.34 & 68.36 & 73.68 & 199.62 & 147.11 & 143.14 \\
\hline Gafsa & 5.80 & 1.86 & 0.74 & 3.87 & 1.50 & 1.04 & 58.91 & 72.56 & 68.17 & 175.37 & 140.03 & 132.99 \\
\hline Sfax & 5.54 & 4.28 & 1.49 & 4.02 & 2.63 & 1.54 & 74.57 & 77.84 & 72.38 & 167.58 & 155.66 & 142.81 \\
\hline Gabes & 4.10 & 3.92 & 1.62 & 2.49 & 2.40 & 1.52 & 72.19 & 73.44 & 68.00 & 162.43 & 149.64 & 138.85 \\
\hline Jerba & 1.50 & 2.12 & 1.17 & 0.95 & 1.04 & 0.88 & 75.93 & 81.84 & 77.52 & 143.26 & 143.90 & 138.52 \\
\hline Tataouine & 2.38 & 3.52 & 2.59 & 1.54 & 1.62 & 1.49 & 73.35 & 71.89 & 63.71 & 147.91 & 149.08 & 138.53 \\
\hline Kebili & 1.88 & 1.51 & 1.52 & 0.59 & 0.39 & 0.61 & 72.37 & 68.18 & 63.90 & 138.33 & 131.06 & 132.72 \\
\hline El Borma & 0.89 & 1.65 & 1.50 & 0.60 & 0.51 & 0.47 & 68.71 & 70.23 & 59.61 & 126.32 & 128.65 & 120.57 \\
\hline
\end{tabular}

Figures 1-4 show the temporal distribution of the monthly mean concentrations of these pollutants at ground level for all Tunisian regions for the years 2019, 2020 and 2021. These show us that the majority of months of the year 2020 and 2021 showed a decrease in concentration of the three pollutants compared to the previous year; namely nitrogen dioxide $\left(\mathrm{NO}_{2}\right)$, sulfur dioxide $\left(\mathrm{SO}_{2}\right)$ and carbon monoxide $(\mathrm{CO})$, while also a slight rise in ozone $\left(\mathrm{O}_{3}\right)$. In a comparison between the first period of COVID-19 in 2020 and the same period of the previous year (2019), the sulfur dioxide $\left(\mathrm{SO}_{2}\right)$ concentration shows a sharp decrease in most Tunisian regions, with a decrease between 50\% and $74 \%$ for 2020 and between $46 \%$ and $80 \%$ for 2021 (Figure 1). The mean monthly concentration of this gas in April 2020, the month characterized by total confinement in Tunisia, was $3.85 \mu \mathrm{g} / \mathrm{m}^{3}$, and was $1.35 \mu \mathrm{g} / \mathrm{m}^{3}$ for 2021. The maximum was in Grand-Tunis; this region had a mean of $28.84 \mu \mathrm{g} / \mathrm{m}^{3}$ and $3.66 \mu \mathrm{g} / \mathrm{m}^{3}$ for April 2020 and 2021, respectively. The minimum was in the Seliana region, with a mean of $1.48 \mu \mathrm{g} / \mathrm{m}^{3}$ and $0.58 \mu \mathrm{g} / \mathrm{m}^{3}$ at Kasserine and Thala regions for April 2020 and 2021, respectively. Additionally, all Tunisian regions were 
characterized by nitrogen dioxide $\left(\mathrm{NO}_{2}\right)$ decreases from January to April 2020 compared to the same period of the previous year, showing a decrease between $24 \%$ and $61 \%$ for 2020 and between $27 \%$ and $52 \%$ for 2021 (Figure 2). The monthly mean concentration of this gas for April 2020 was $4.69 \mu \mathrm{g} / \mathrm{m}^{3}$, and $2.49 \mu \mathrm{g} / \mathrm{m}^{3}$ for April 2021. The maximum was in the Grand-Tunis region with a mean of $22.49 \mu \mathrm{g} / \mathrm{m}^{3}$ and $11.1 \mu \mathrm{g} / \mathrm{m}^{3}$ for April 2020 and 2021, respectively. The minimum was in the Kebili region, with a mean of $0.44 \mu \mathrm{g} / \mathrm{m}^{3}$ and $0.61 \mu \mathrm{g} / \mathrm{m}^{3}$ for April 2020 and 2021, respectively. On the other hand, the Tunisian regions recorded a slight increase in the ozone concentration $\left(\mathrm{O}_{3}\right)$ from January to April 2020 compared to the same period of the previous year, showing a growth between $1 \%$ and $23 \%$ for 2020 and between $4 \%$ and $6 \%$ for 2021, except for the month of March 2021 where it presented a decrease of $2 \%$ (Figure 3). The values of the monthly mean concentration of this gas were $59.26 \mu \mathrm{g} / \mathrm{m}^{3}$ for April 2020 and $62.77 \mu \mathrm{g} / \mathrm{m}^{3}$ for the same month in 2021. The maximum was in the Djerba Ile region, with a mean of $80.42 \mu \mathrm{g} / \mathrm{m}^{3}$ and $80.74 \mu \mathrm{g} / \mathrm{m}^{3}$ in the Kelibia region for April 2020 and 2021, respectively. The minimum was in the Grand-Tunis region with a mean of $33.50 \mu \mathrm{g} / \mathrm{m}^{3}$ and $42 \mu \mathrm{g} / \mathrm{m}^{3}$ in the Jendouba region for April 2020 and 2021, respectively. Finally, the Tunisian regions have recorded a decrease in the carbon monoxide concentration (CO) from January to April 2020 compared to the same period of the previous year, showing a decrease between $11 \%$ and 35\% for 2020 and between $1 \%$ and $21 \%$ for 2021, except for the month of February 2021 where it presented a small rise of $3 \%$ (Figure 4). The mean of the monthly concentration of this gas was $164.86 \mu \mathrm{g} / \mathrm{m}^{3}$ for April 2020, and $145.94 \mu \mathrm{g} / \mathrm{m}^{3}$ for the same month in 2021. The maximum was in the Grand-Tunis region with a mean of $361.00 \mu \mathrm{g} / \mathrm{m}^{3}$ and $265.43 \mu \mathrm{g} / \mathrm{m}^{3}$ for April 2020 and 2021 respectively. The minimum was in the El Borma region with a mean of $129.45 \mu \mathrm{g} / \mathrm{m}^{3}$ and $120.57 \mu \mathrm{g} / \mathrm{m}^{3}$ for April 2020 and 2021, respectively.

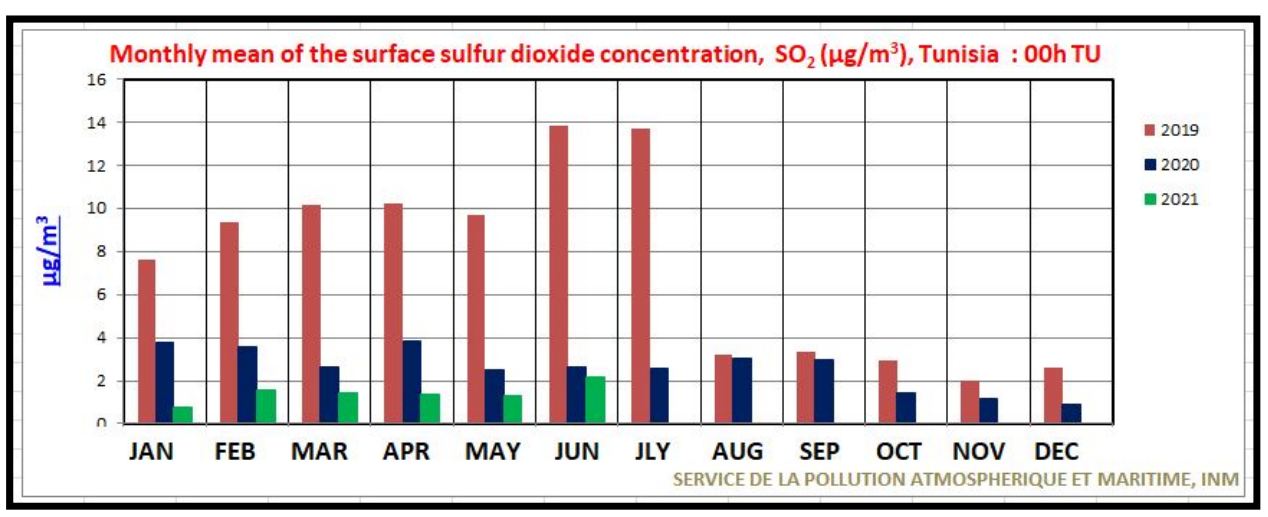

Figure 1. Monthly mean of the surface sulfur dioxide concentration, $\mathrm{SO}_{2}\left(\mu \mathrm{g} / \mathrm{m}^{3}\right)$, before and after the confinement 2019-2021 period: Tunisia, 00h UTC.

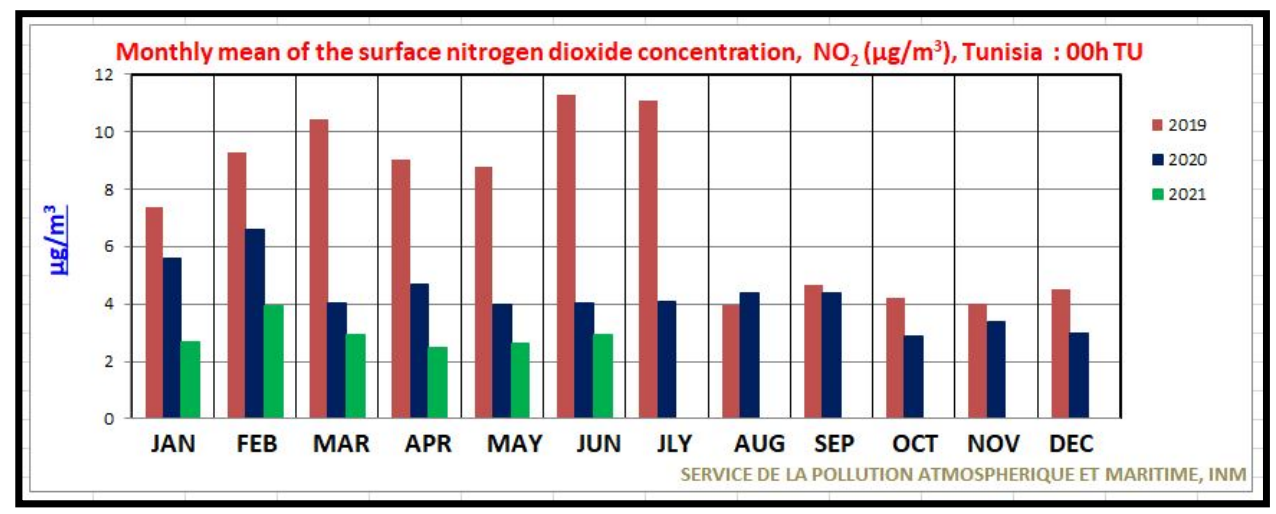

Figure 2. Monthly mean of the surface nitrogen dioxide concentration, $\mathrm{NO}_{2}\left(\mu \mathrm{g} / \mathrm{m}^{3}\right)$, before and after the confinement 2019-2021 period: Tunisia, 00h UTC. 


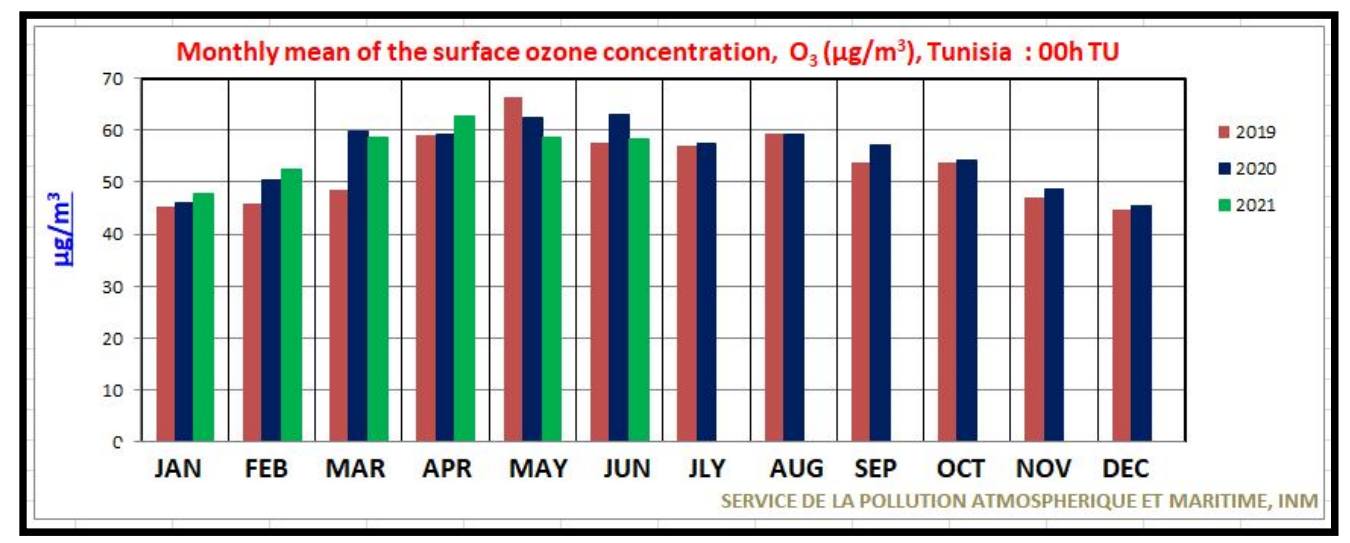

Figure 3. Monthly mean of the surface ozone concentration, $\mathrm{O}_{3}\left(\mu \mathrm{g} / \mathrm{m}^{3}\right)$, before and after the confinement 2019-2021 period: Tunisia, 00h UTC.

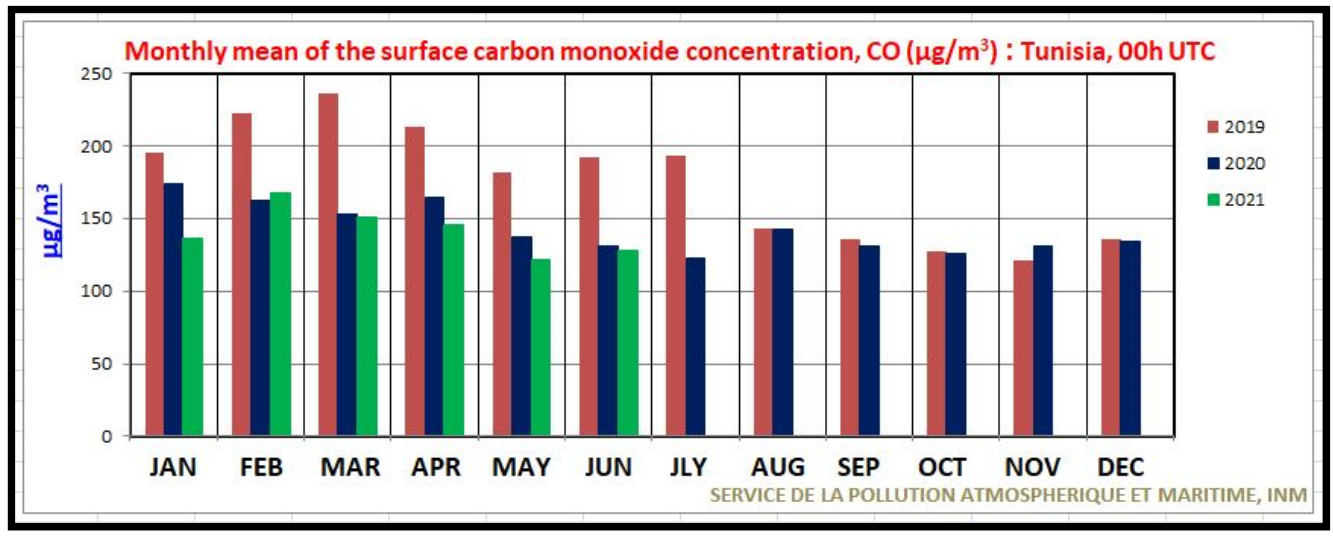

Figure 4. Monthly mean of the surface carbon monoxide concentration, $\mathrm{CO}\left(\mu \mathrm{g} / \mathrm{m}^{3}\right)$, before and after the confinement 2019-2021 period: Tunisia, 00h UTC.

Thus, Figures 5-8 present the regional distribution of the monthly concentration means of all the pollutants for the month of April 2019, 2020 and 2021; this month acting as a reference period of total or partial confinement for the years 2020 and 2021, where low and high concentration regions of these pollutants appear at ground level. The pollutants are mainly related to various environmental and meteorological factors where the general atmospheric circulation affects them. These regional distributions show a remarkable decrease in sulfur dioxide $\left(\mathrm{SO}_{2}\right)$ for the years 2020 and 2021; years referenced for COVID-19 occurrence compared to the previous year. For all Tunisian regions, this decrease was $62 \%$ and $65 \%$ for April 2020 and 2021, respectively (Figure 5). A larger decrease occurred more in the west of the country, mainly caused by high industry concentration in coastal regions. For the nitrogen dioxide $\left(\mathrm{NO}_{2}\right)$, its decrease was $48 \%$ and $47 \%$ for April 2020 and 2021, respectively (Figure 6). A larger decrease occurred more in the north and the center of the country than in the south. In addition, the regional distributions for the ozone concentration $\left(\mathrm{O}_{3}\right)$ show a slight increase for the years 2020 and 2021, compared to the previous year. This growth was 1\% and 6\% for April 2020 and 2021, respectively (Figure 7). The increase occurs more in the north than in the center and the south. Finally, the regional distributions of carbon monoxide (CO) also show a decrease for the years 2020 and 2021, compared to the previous year. This decrease was 22\% and 11\% for April 2020 and 2021, respectively (Figure 8). A larger decrease occurred more in the north of all Tunisian regions than in the center and the south. 


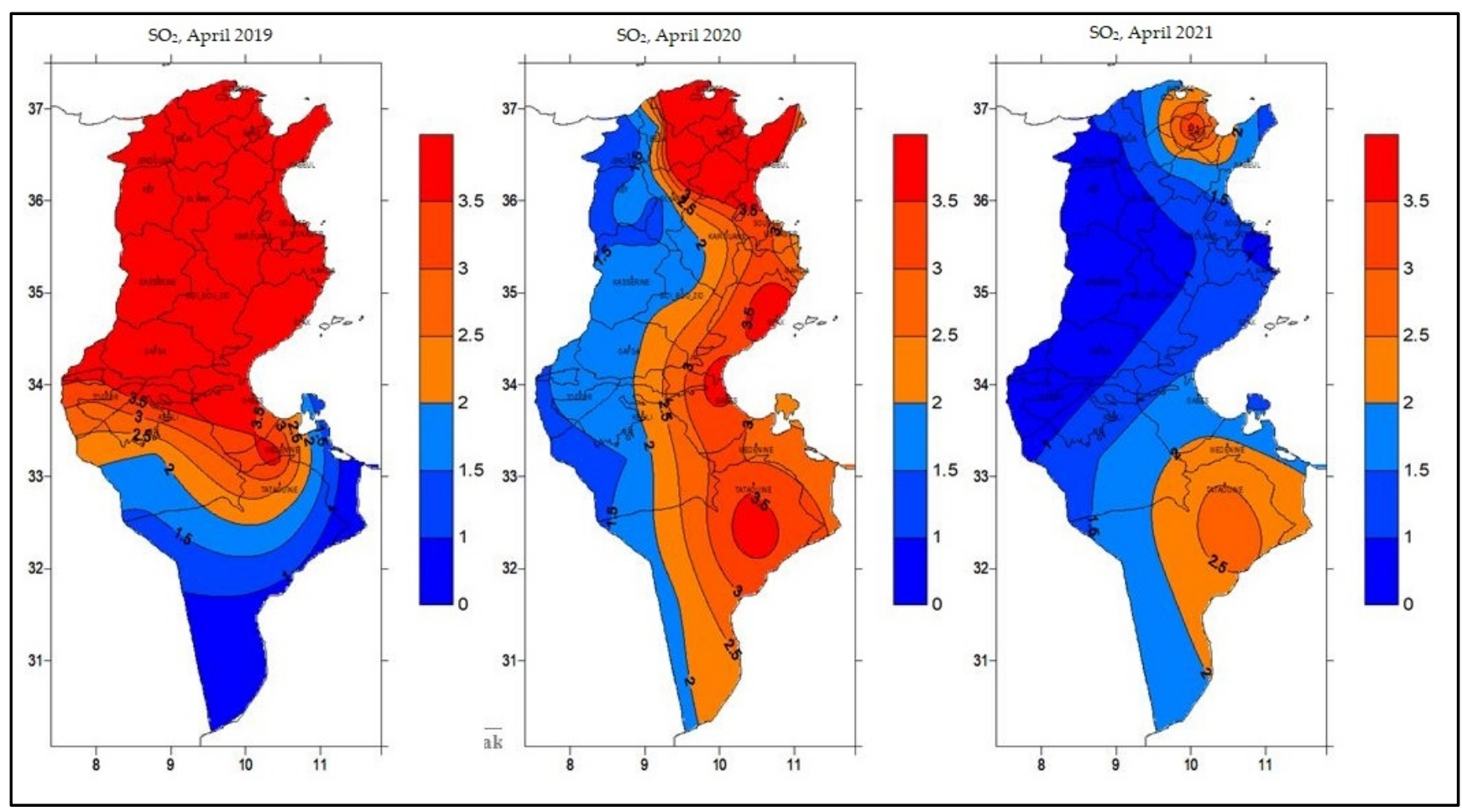

Figure 5. Regional distribution of the monthly mean sulfur dioxide concentration $\left(\mathrm{SO}_{2}\right)$ at ground level for April in 2019 , 2020 and 2021 (unit $\mu \mathrm{g} / \mathrm{m}^{3}$ ).

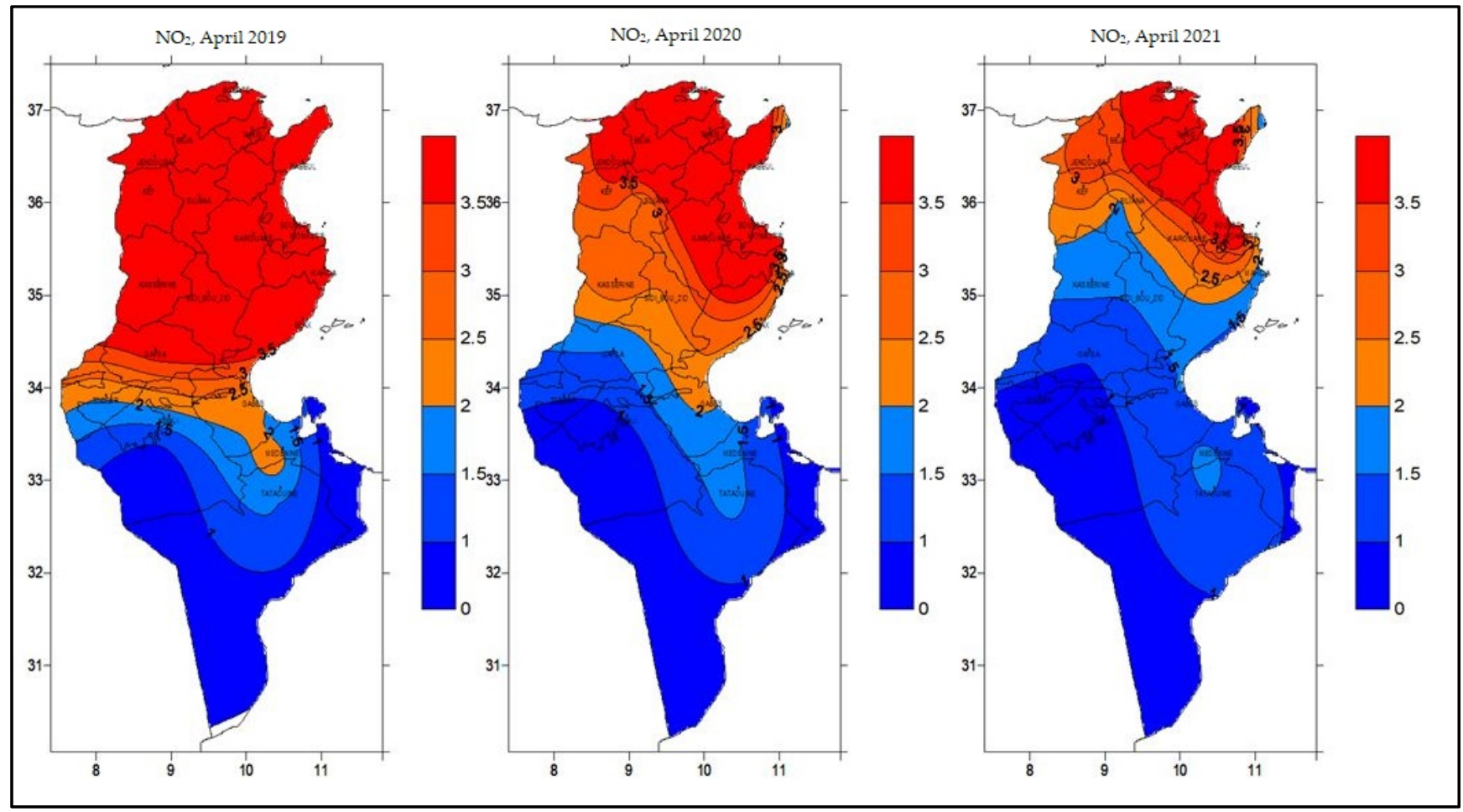

Figure 6. Regional distribution of the monthly mean nitrogen dioxide concentration $\left(\mathrm{NO}_{2}\right)$ at ground level for April in 2019 , 2020 and 2021 (unit $\mu \mathrm{g} / \mathrm{m}^{3}$ ). 


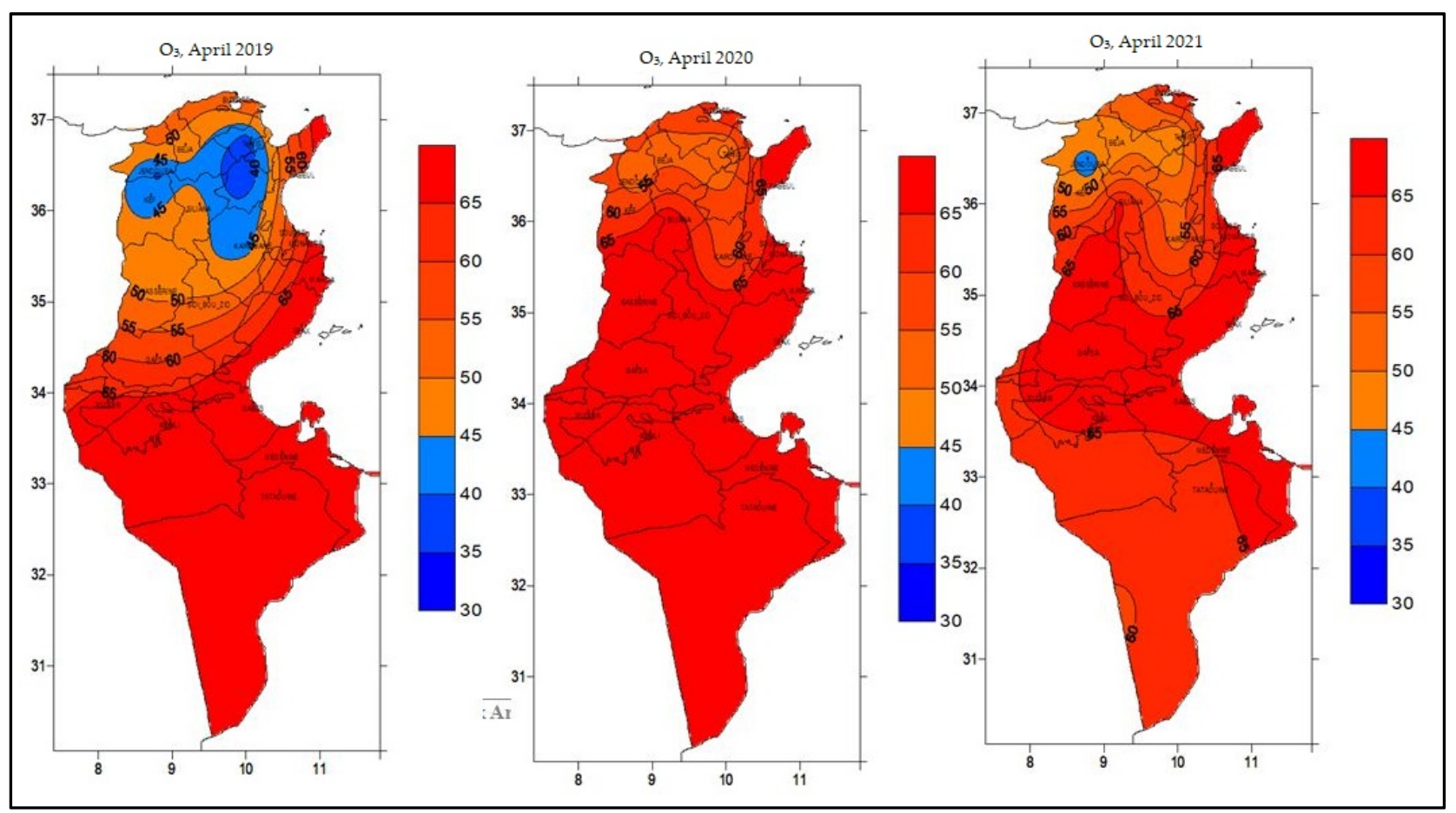

Figure 7. Regional distribution of the monthly mean ozone concentration $\left(\mathrm{O}_{3}\right)$ at ground level for April in 2019,2020 and 2021 (unit $\mu \mathrm{g} / \mathrm{m}^{3}$ ).

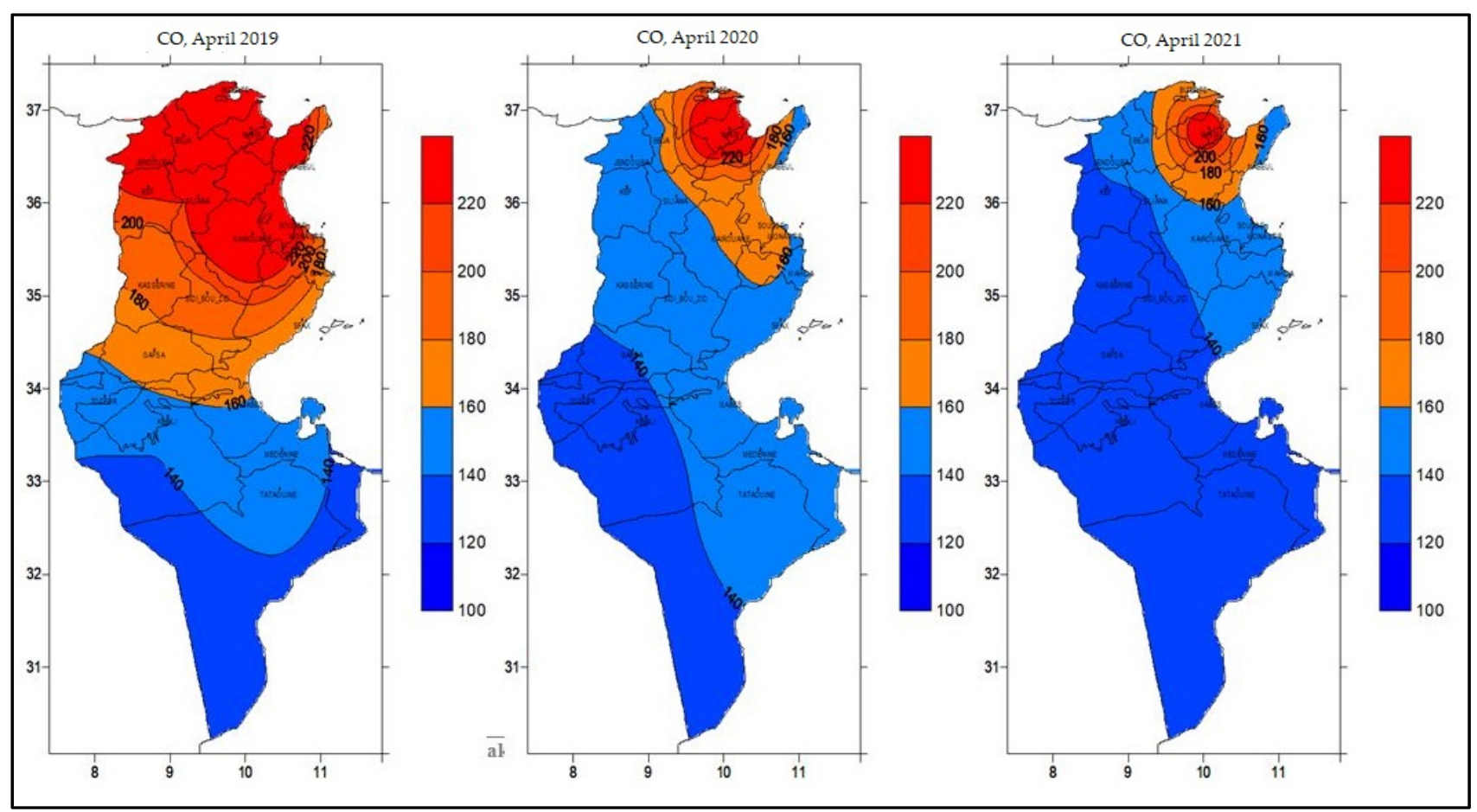

Figure 8. Regional distribution of the monthly mean carbon monoxide concentration (CO) at ground level for April in 2019, 2020 and 2021 (unit $\mu \mathrm{g} / \mathrm{m}^{3}$ ).

\section{Conclusions}

Since the first coronavirus case appearance (COVID-19), reported in Wuhan, China, the Tunisian government has taken a protective measures series to limit its spread at a national scale. Travel between cities is prohibited. Factories have been closed to limit 
human damage. International flights have been halted and the majority of government and private services have been halted except minimum and emergency services. These unique circumstances are perfect for the study of human behaviour's impact on air pollution in Tunisia. We conducted this research to study the possible impacts of human behaviour following the COVID-19 pandemic on the air pollution in Tunisia. We used hourly atmospheric pollutant concentrations collected from Sentinel-5P satellite data from the European COPERNICUS program. The mean monthly concentrations tendency analysis of air pollutants during the end March and April 2020, a period of total confinement in Tunisia, showed significant reductions of $\mathrm{SO}_{2}, \mathrm{NO}_{2}$ and $\mathrm{CO}$. This reduction is more pronounced in the north and the center of Tunisia. A comparison of these pollutants revealed that the concentrations of almost all the pollutants had decreased compared to the same period of the previous year. The concentration of sulfur dioxide $\left(\mathrm{SO}_{2}\right)$ was lowered in the majority of Tunisian cities, mainly in April 2020, except the southern Tunisian regions which have not experienced a remarkable change in this concentration. This decrease at ground level was visibly remarkable at the beginning of 2021, especially during the third COVID-19 pandemic wave (January to April 2021). In reality, this decrease depends mainly on several environmental and meteorological factors. For example, the atmospheric general circulation directly affects the pollutant concentration. There are several factors that can affect air pollutant concentration. Local meteorological parameters such as temperatures, thunderstorm occurrence with high air temperatures, or forest fire occurrence, could affect atmosphere stability, and in the presence of high atmospheric pressure, could influence these concentrations. We have also noted that nitrogen dioxide $\left(\mathrm{NO}_{2}\right)$ and carbon monoxide (CO) concentrations decreased in the majority of Tunisian regions. The largest decrease was observed in the Grand-Tunis region. Furthermore, notable increases in $\mathrm{O}_{3}$ were observed in the majority of Tunisian regions. The air quality appears to be improved in almost all regions following the introduction of government COVID-19 pandemic protective measures. Thus, this study shows that the gradual limitation of industrial activity and automobile traffic in Tunisia caused by COVID-19 pandemic protective measures have been accompanied by an apparent decrease in air pollution and air quality index in Tunisian regions. In other words, the effect of this horrible virus has brought us back to cleaner air.

Funding: No funding was received for conducting this study.

Acknowledgments: The author gratefully thanks to COPERNICUS program for satellite measurements used in this publication and for accepting me as a researcher for the development of this research. I also thank the Tunisian National Meteorological Institute (INM) for encouraging me in the of research field concerning the air quality in Tunisia. My gratefully acknowledge to Anthony R. Lupo, Chair of the 4th International Electronic Conference on Atmospheric Sciences (ECAS2021) for his efforts. Finally, I also thank the Environmental Sciences Proceedings Editorial Office (MDPI) staff for their contribution to the revision of this article and its acceptance for publication in the Journal Environmental Sciences Proceedings.

\section{References}

1. Huang, C.; Wang, Y.; Li, X.; Ren, L.; Zhao, J.; Hu, Y.; Zhang, L.; Fan, G.; Xu, J.; Gu, X.; et al. Clinical features of patients infected with 2019 novel coronavirus in Wuhan, China. Lancet 2020, 395, 497-506. [CrossRef]

2. Chan, J.F.-W.; Yuan, S.; Kok, K.-H.; To, K.K.-W.; Chu, H.; Yang, J.; Xing, F.; Liu, J.; Yip, C.C.-Y.; Poon, R.W.-S.; et al. A familial cluster of pneumonia associated with the 2019 novel coronavirus indicating person-to-person transmission: A study of a family cluster. Lancet 2020, 395, 514-523. [CrossRef]

3. WHO. Novel Coronavirus (2019-nCoV) Situation Report-1 (21 January 2020); World Health Organization: Geneva, Switzerland, 2020.

4. Wilder-Smith, A.; Freedman, D.O. Isolation, quarantine, social distancing and community containment: pivotal role for old-style public health measures in the novel coronavirus (2019-nCoV). J. Travel Med. 2020, 1-4. [CrossRef] [PubMed]

5. Wang, Q.; Su, M. A preliminary assessment of the impact of COVID-19 on environment-A case study of China. Sci. Total Environ. 2020, 728, 138915. [CrossRef] [PubMed]

6. Arif, A. Confinement and Coronavirus: Falling Air Pollution in Tunisia; Technical Report; National Institute of Meteorology: Tunis, Tunisia, 2020; 32p. Available online: https:/ / www.meteo.tn/sites/default/files/2020-05/Rapport-18-05-2020_en.pdf (accessed on 9 September 2021). 
7. Crouse, D.L.; Peters, P.A.; Hystad, P.; Brook, J.R.; van Donkelaar, A.; Martin, R.V.; Villeneuve, P.J.; Jerrett, M.; Goldberg, M.S.; Pope, C.A.; et al. Ambient $\mathrm{PM}_{2.5}, \mathrm{O}_{3}$, and $\mathrm{NO}_{2}$ exposures and associations with mortality over 16 Years of follow-up in the Canadian census health and environment cohort (CanCHEC). Environ. Health Perspect. 2015, 123, 1180-1186. [CrossRef] [PubMed]

8. He, L.; Zhang, S.; Hu, J.; Li, Z.; Zheng, X.; Cao, Y.; Xu, G.; Yan, M.; Wu, Y. On-road emission measurements of reactive nitrogen compounds from heavy-duty diesel trucks in China. Environ. Pollut. 2020, 262, 114280. [CrossRef] [PubMed]

9. He, M.Z.; Kinney, P.L.; Li, T.; Chen, C.; Sun, Q.; Ban, J.; Wang, J.; Liu, S.; Goldsmith, J.; Kioumourtzoglou, M.-A. Short- and intermediate-term exposure to $\mathrm{NO}_{2}$ and mortality: A multi-county analysis in China. Environ. Pollut. 2020, 261, 114165. [CrossRef] [PubMed]

10. Ortiz, C.; Linares, C.; Carmona, R.; Díaz, J. Evaluation of short-term mortality attributable to particulate matter pollution in Spain Environ. Pollut. 2017, 224, 541-551. [CrossRef] [PubMed]

11. Gope, S.; Dawn, S.; Das, S.S. Effect of COVID-19 pandemic on air quality: A study based on Air Quality Index. Environ. Sci. Pollut. Res. 2020, 28, 35564-35583. [CrossRef] [PubMed]

12. Brauer, M. How much, how long, what, and where: Air pollution exposure assessment for epidemiologic studies of respiratory disease. Proc. Am. Thorac. Soc. 2010, 7, 111-115. [CrossRef] [PubMed]

13. Chen, S.; Bloom, D.E. The macroeconomic burden of noncommunicable diseases associated with air pollution in China. PLoS ONE 2019, 14, e0215663. [CrossRef] [PubMed]

14. Cohen, A.J.; Brauer, M.; Burnett, R.; Anderson, H.R.; Frostad, J.; Estep, K.; Balakrishnan, K.; Brunekreef, B.; Dandona, L.; Dandona, R.; et al. Estimates and 25-year trends of the global burden of disease attributable to ambient air pollution: An analysis of data from the Global Burden of Diseases Study 2015. Lancet 2017, 389, 1907-1918. [CrossRef]

15. European Environment Agency. Communication from the Commission to the Council and the European Parliament-Thematic Strategy on Air Pollution. (COM(2005) 0446 Final); European Environment Agency: Copenhagen, Denmark, 2005.

16. Rohde, R.A.; Muller, R.A. Air Pollution in China: Mapping of Concentrations and Sources. Berkeley Earth 2015, 10, e0135749. [CrossRef] [PubMed]

17. Wang, H.; Dwyer-Lindgren, L.; Lofgren, K.T.; Rajaratnam, J.K.; Marcus, J.R.; Levin-Rector, A.; Levitz, C.E.; Lopez, A.D.; Murray, C.J.L. Age-specific and sex-specific mortality in 187 countries, 1970-2010: A systematic analysis for the Global Burden of Disease Study 2010. Lancet 2012, 380, 2071-2094. [CrossRef]

18. Chiusolo, M.; Cadum, E.; Stafoggia, M.; Galassi, C.; Berti, G.; Faustini, A.; Bisanti, L.; Vigotti, M.A.; Dessì, M.P.; Cernigliaro, A.; et al. EpiAir Collaborative Group Short-Term effects of nitrogen dioxide on mortality and susceptibility factors in 10 Italian cities: The EpiAir study. Environ. Health Perspect. 2011, 119, 1233-1238. [CrossRef] [PubMed]

19. Hoek, G.; Krishnan, R.M.; Beelen, R.; Peters, A.; Ostro, B.; Brunekreef, B.; Kaufman, J.D. Long-term air pollution exposure and cardio respiratory mortality: A review. Environ. Health 2013, 12, 43. [CrossRef] [PubMed]

20. Arif, A. Lightning Activity and Climate Change with NCEP and CRCM Data: Canada and Northern United States Regions; Editions Universitaires Européennes: Saarbrücken, Germany, 2012; 136p, ISBN 978-3-8417-9647-9. 